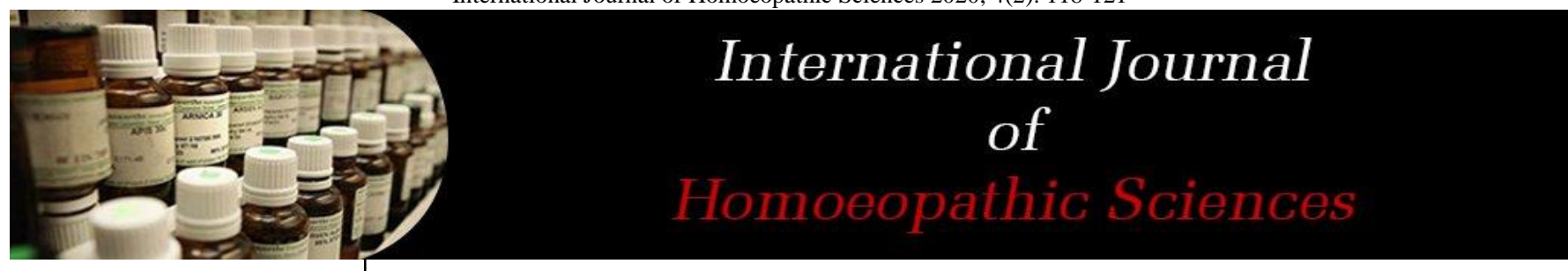

E-ISSN: 2616-4493 P-ISSN: 2616-4485 www.homoeopathicjournal.com IJHS 2020; 4(2): 118-121 Received: 25-02-2020 Accepted: 27-03-2020

Vijayasankari A M.Sc Public Health, Department of Epidemiology, The Tamil Nadu Dr MGR Medical University, Guindy, Chennai, Tamil Nadu, India

Indra S

M.Sc Public Health, Department of Epidemiology, The Tamil Nadu Dr MGR Medical University, Guindy, Chennai, Tamil Nadu, India

Kalpana T

M.Sc Epidemiology, Department of Epidemiology, The Tamil Nadu Dr MGR Medical University,

Guindy, Chennai, Tamil Nadu, India

Kalpana S

Research Officer, Department of Epidemiology, The Tamil Nadu Dr MGR Medical University, Guindy, Chennai, Tamil Nadu, India
Corresponding Author:

Vijayasankari A

M.Sc Public Health,

Department of Epidemiology,

The Tamil Nadu Dr MGR

Medical University,

Guindy, Chennai, Tamil Nadu, India

\section{COVID 19 and homeopathy medicine: A brief review}

\author{
Vijayasankari A, Indra S, Kalpana T and Kalpana S
}

DOI: https://doi.org/10.33545/26164485.2020.v4.i2b.159

\begin{abstract}
The newest member of the coronavirus family $(2019-\mathrm{nCoV})$ has been recently identified that results in acute and severe respiratory syndrome in humans. The first infected patient who had clinical manifestations such as fever, cough, and dyspnea was reported on 12 December 2019 in Wuhan, China. In-vitro studies have shown that chloroquine is effective against several viruses, including severe acute respiratory syndrome coronavirus (SARS-CoV). Multiple mechanisms of action have been identified for chloroquine that disrupt the early stage of coronavirus replication. The use of homeopathy for epidemic diseases dates back to the time of Hahnemann, who recommended Belladonna for scarlet fever. It is interesting to note that homeopathy was invented in the same year as Jenner first practiced vaccination (1796) and that Hahnemann strongly favored vaccination. The AYUSH ministry issued a health advisory and recommended that homeopathic and unani medicines could be effective in the prevention of novel coronavirus $(\mathrm{nCoV})$ infections.
\end{abstract}

Keywords: Covid 19, homeopathy medicine, arsenic album-30

\section{Introduction}

The newest member of the coronavirus family $(2019-\mathrm{nCoV})$ has been recently identified that results in acute and severe respiratory syndrome in humans. The first infected patient who had clinical manifestations such as fever, cough, and dyspnea was reported on 12 December 2019 in Wuhan, China (1) According to the WHO, the outbreak of coronavirus disease 2019 (COVID-19) has become a pandemic, which at the time of writing had affected over 4,312,716 people and caused over 2,90,945 deaths worldwide ${ }^{[2]}$. Previously, the severe acute respiratory syndrome-coronavirus (SARS-CoV) and the Middle East respiratory syndrome-coronavirus (MERS-CoV) have been known to affect humans. Outbreaks of respiratory disease caused by these viruses seem to have originated in animals before moving into other hosts like humans. MERS-CoV was found to be transmitted from Arabian camels to humans, whereas SARS-CoV was transmitted from civet cats to humans. SARS-CoV-2 seems to have originated from bats and first reports of cases were from Wuhan, Hubei Province in China, suggesting an animal-to-person spread from a live animal market. The virus then spread outside Hubei and subsequently, to the rest of the world via human transmission. Several countries have now reported community spread ${ }^{[3]}$. In order to introduce and install effective control measures, having knowledge about basic hygiene principles and modes of disease transmission, and measures in such an environment is, therefore, of vitally importance ${ }^{[4]}$.

\section{Epidemiology of Covid-19}

Geographic distribution: Globally, more than four million confirmed cases of COVID-19 have been reported. The first four cases of an acute respiratory syndrome of unknown etiology were identified among people linked to a local seafood market ("wet market") in Wuhan City China on 29 December 2019. The research is under progress to learn more about COVID-19-related transmissibility, frequency and other features ${ }^{[5]}$. Early identified cases have had some history of contact with the market in seafood.

\section{Agent}

Coronavirus are the big family of different viruses. Coronaviruses (family Coronaviridae, subfamily Coronavirinae) are important pathogens of birds and mammals. Coronaviruses are positive-sense RNA viruses and are currently classified into four genera: Alpha coronavirus, Beta coronavirus, Gamma coronavirus, and Delta coronavirus. (6) Coronaviruses have enveloped virions (virus particles) that measure approximately $120 \mathrm{~nm}\left(1 \mathrm{~nm}=10^{-9}\right.$ metre $)$ in diameter. 
Club-shaped glycoprotein spikes in the envelope give the viruses a crownlike or coronal, appearance. The nucleocapsid, made up of a protein shell known as a capsid and containing the viral nucleic acids, is helical or tubular. The coronavirus genome consists of a single strand of positive-sense RNA (ribonucleic acid) ${ }^{[7]}$.

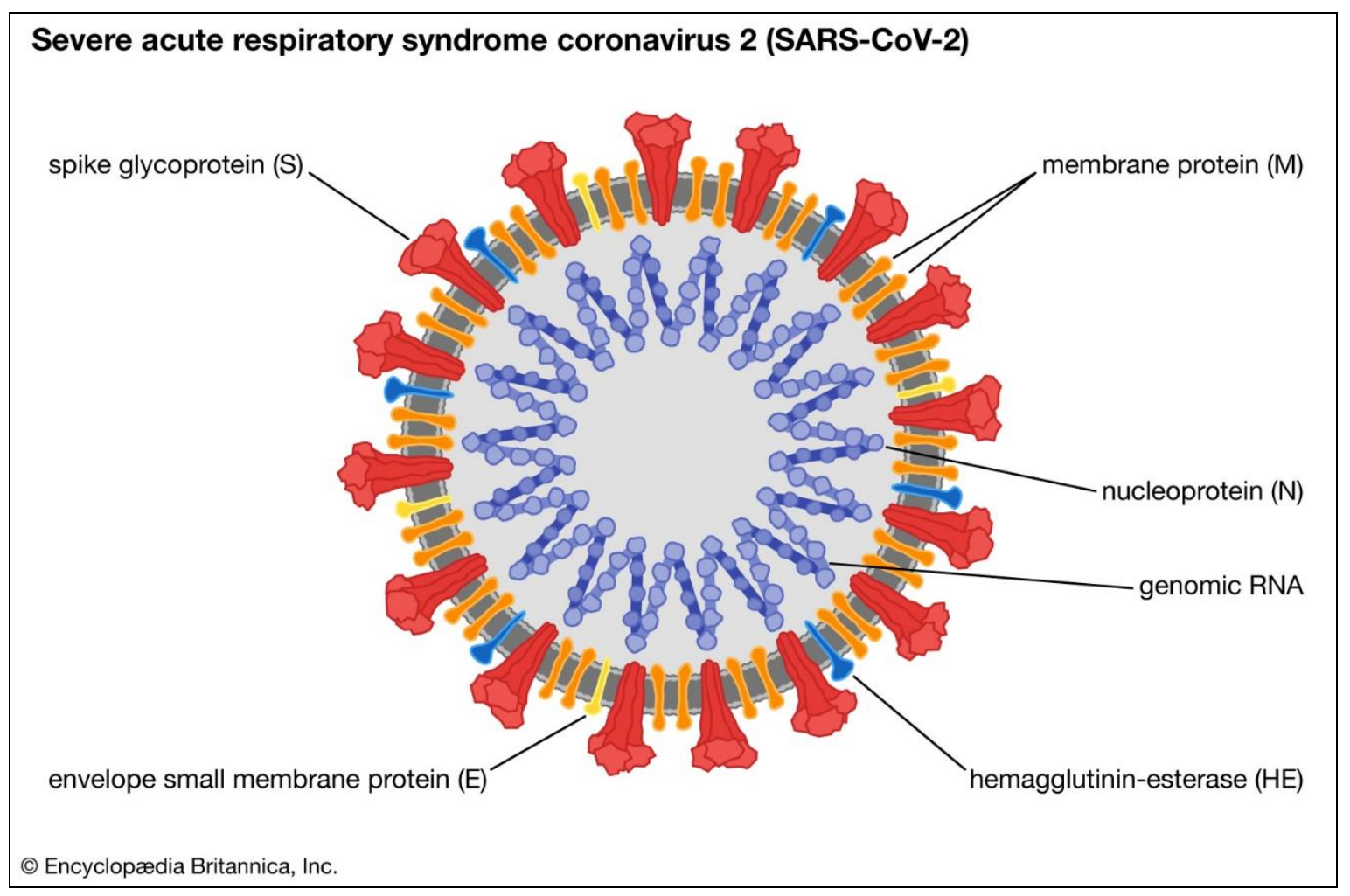

Fig 1: SARS-CoV-2

\section{SARS-CoV-2}

The coronavirus SARS-CoV-2, the cause of the COVID-19 pandemic.

Source: Encyclopædia Britannica

\section{Mode of Transmission}

It is anticipated that there is probable zoonotic origin of COVID19, based on the large number of infected people who were exposed to the wet animal market in Wuhan City where live animals are routinely sold. Efforts were made to look for a host reservoir or intermediate carriers from which the infection could spread to humans ${ }^{[5]}$. The possibility of transmission is not well understood. Initial association with a market that sold live animals, where most patients had been employed or visited and which was subsequently closed to disinfection was established by epidemiologic research at the beginning of Wuhan's outbreak. However, with the epidemic increasing, the main mode of dissemination has been the distribution of individuals.

Respiratory infections can be transmitted through droplets of different sizes: when the droplet particles are $>5-10 \mu \mathrm{m}$ in diameter they are referred to as respiratory droplets, and when then are $<5 \mu \mathrm{m}$ in diameter, they are referred to as droplet nuclei ${ }^{[8]}$.

\section{Path of Treatment so far}

There are no specific treatment exist right now. Yet some of the same things can be done to make people feel better when they have influenza, rest well, remain well hydrated, and take medications to help alleviate fatigue, pain and aches. In the meantime, scientists are working hard to develop effective treatments. Therapies that are under investigation include drugs that have been used to treat malaria and autoimmune diseases; antiviral drugs that were developed for other viruses, and antibodies from people who have recovered from COVID-19 [9]

\section{Hydroxychloroquine}

In-vitro studies have shown that chloroquine is effective against several viruses, including severe acute respiratory syndrome coronavirus (SARS-CoV). Multiple mechanisms of action have been identified for chloroquine that disrupt the early stage of coronavirus replication. Moreover, chloroquine affects immune system activity by mediating an anti-inflammatory response, which might reduce damage due to the exaggerated inflammatory response ${ }^{[10]}$.

\section{Convalescent plasma therapy}

Convalescent plasma therapy involves transfusing certain components from the blood of people who have recovered from a virus attack into people who are very sick with the virus or at high risk ${ }^{[11]}$. Plasma therapy treats patients by transferring the immunity from a healthy person to a sick person. The therapy uses antibodies from the blood of the recovered coronavirus patient to treat another critical patient. This helps the infected person to develop antibodies needed against the COVID 19 virus. The antibodies when transferred start fighting against coronavirus.

\section{Homeopathy in Epidemic and pandemic}

The use of homeopathy for epidemic diseases dates back to the time of Hahnemann, who recommended Belladonna for scarlet fever. It is interesting to note that homeopathy was invented in the same year as Jenner first practiced 
vaccination (1796) and that Hahnemann strongly favored vaccination ${ }^{[12]}$ In the year 1852, Dr. Routh, a British allopathic physician and an opponent of homeopathy, was a designated authority by medical officials of London to release the mortality-statistics (for all diseases). As a result of his findings, Dr. Routh was constrained to testify in favor of homeopathy. He collected statistics of different hospitals (England, Austria and Germany), total of 32,655 homeopathic cases and 119,630 allopathic cases. The overall mortality under homeopathic treatment was 4.4 percent, and the overall mortality under allopathic treatment was 10.5 percent ${ }^{[13]}$

Table 1: Treatment history by Homeopathy

\begin{tabular}{|c|c|c|c|c|c|}
\hline Year & Location & Disease & Treatment by Homeopathy & Treatment by Allopathy & $\begin{array}{l}\text { Treatment } \\
\text { with No } \\
\text { Medicine } \\
\end{array}$ \\
\hline 1799 & $\begin{array}{l}\text { Königslütter, } \\
\text { Germany }\end{array}$ & $\begin{array}{l}\text { Scarlet } \\
\text { Fever }\end{array}$ & Mortality $<5 \%$ & & \\
\hline $\begin{array}{c}1830 \sim \\
' 31^{*}\end{array}$ & Russia & Cholera & $\begin{array}{l}\text { Mortality } 11 \% \text { Reported by } \\
\text { Imperial Council \& Foreign } \\
\text { Ministry of Russia. }\end{array}$ & $\begin{array}{l}\text { Mortality } 63 \% \text { Reported by } \\
\text { Imperial Council \& Foreign } \\
\text { Ministry of Russia. }\end{array}$ & Not recorded. \\
\hline $\begin{array}{c}1830 \sim \\
1832\end{array}$ & $\begin{array}{l}\text { Vienna, Prague, } \\
\text { Hungary and } \\
\text { Moravia }\end{array}$ & Cholera & $\begin{array}{c}\text { Mortality } 7 \% \text { Reported by Dr. } \\
\text { Kath, appointed by King of } \\
\text { Bavaria. }\end{array}$ & $\begin{array}{l}\text { Mortality } 31 \% \text { Reported by } \\
\text { Dr. Kath, appointed by King } \\
\text { of Bavaria. }\end{array}$ & Not recorded. \\
\hline $1836 * *$ & Vienna & Cholera & $\begin{array}{l}\text { Mortality } 33 \% \text { Lead Homeopath } \\
\text { in charge was Dr. Fleischmann }\end{array}$ & Mortality $66 \%$ & \\
\hline 1847 & Ireland & $\begin{array}{l}\text { Typhus } \\
\text { fever }\end{array}$ & $\begin{array}{l}\text { Mortality } 2 \% \text { Lead Homeopath } \\
\text { in charge was Dr. Joseph Kidd }\end{array}$ & $\begin{array}{c}\text { Mortality } 13 \% \text { Lead Allopath } \\
\text { in charge was Dr. Abraham } \\
\text { Tuckey }\end{array}$ & Not recorded. \\
\hline 1847 & England & $\begin{array}{l}\text { Typhus } \\
\text { fever }\end{array}$ & Mortality $2 \%$ & Mortality $13 \%$ & Mortality $10 \%$ \\
\hline 1848 & $\begin{array}{l}\text { Edinburgh, } \\
\text { Scotland }\end{array}$ & Cholera & $\begin{array}{l}\text { Mortality } 24 \% \text { Reported by } \\
\text { Edinburgh Dispensary. }\end{array}$ & $\begin{array}{l}\text { Mortality } 68 \% \text { Reported by } \\
\text { Edinburgh Dispensary. }\end{array}$ & Not recorded. \\
\hline $\begin{array}{c}\text { mid } \\
1800 \text { 's }\end{array}$ & Austria & Pneumonia & $\begin{array}{l}\text { Mortality } 5 \% \text { Lead Homeopath } \\
\text { in charge was Dr. Fleischmann }\end{array}$ & $\begin{array}{l}\text { Mortality } 20 \% \text { Lead Allopath } \\
\text { in charge was Dr. Dietl }\end{array}$ & Not recorded. \\
\hline $\begin{array}{c}1853 \sim \\
1855\end{array}$ & South of America & Yellow fever & $\begin{array}{l}\text { Mortality } 5.4 \% \text { Lead } \\
\text { Homeopaths in charge were Dr. } \\
\text { F. Davis and Dr. W. Holconibe }\end{array}$ & Not Available. & Not recorded. \\
\hline 1854 & London, England & Cholera & $\begin{array}{l}\text { Mortality } 16.4 \% \text { Reported by } \\
\text { Royal College of Physicians. }\end{array}$ & $\begin{array}{l}\text { Mortality 59.2 \%Reported by } \\
\text { Royal College of Physicians. }\end{array}$ & Not recorded. \\
\hline 1878 & New Orleans, USA & Yellow fever & $\begin{array}{c}\text { Mortality 5.6\%Special } \\
\text { Commission reported the } \\
\text { statistics. }\end{array}$ & $\begin{array}{l}\text { Mortality } 17 \% \text { Special } \\
\text { Commission reported the } \\
\text { statistics. }\end{array}$ & Not recorded. \\
\hline $1918 * * *$ & Pittsburgh, USA & $\begin{array}{l}\text { Spanish } \\
\text { Influenza }\end{array}$ & $\begin{array}{l}\text { Mortality } 1.05 \% \text { Reported by } \\
\text { Dean, Pittsburgh Hospital }\end{array}$ & $\begin{array}{l}\text { Mortality } 30 \% \text { Reported by } \\
\text { Dean, Pittsburgh Hospital }\end{array}$ & Not recorded. \\
\hline
\end{tabular}

Source: (13)

\section{Arsenicum Album}

\section{Arsenious Acid-Arsenic Trioxide}

A profoundly acting remedy on every organ and tissue. Its clear-cut characteristic symptoms and correspondence to many severe types of disease make its homeopathic employment constant and certain. Its general symptoms often alone lead to its successful application. Among these the all-prevailing debility, exhaustion, and restlessness, with nightly aggravation, are most important. Great exhaustion after the slightest exertion. This, with the peculiar irritability of fiber, gives the characteristic irritable weakness. Burning pains. Unquenchable thirst. Burning relieved by heat. Seaside complaints (Nat mur; Aqua Marina). Injurious effects of fruits, especially more watery ones. Gives quiet and ease to the last moments of life when given in high potency. Fear fright and worry. Green discharges. Infantile Kala-azar (Dr. Neatby). Ars should be thought of in ailments from alcoholism, ptomaine poisoning, stings, dissecting wounds, chewing tobacco; ill effects from decayed food or animal matter; odor of discharges is putrid; in complaints that return annually. Anæmia and chlorosis. Degenerative changes. Gradual loss of weight from impaired nutrition. Reduces the refractive index of blood serum (also China and Ferr phos). Maintains the system under the stress of malignancy regardless of location. Malarial cachexia. Septic infections and low vitality ${ }^{[14]}$.

Arsenic is a trace element. It is found in several foods including seafood, poultry, grains (especially rice), bread, cereal products, mushrooms, and dairy products. Some forms of arsenic are used as medicine ${ }^{[15]}$. Vials of Arsenicum Album - 30 - a compound known to treat a range of symptoms such as insomnia, digestive disorders, allergies, anxiety and even depression - are flying off the shelves of homeopaths after the AYUSH Ministry declared it a "preventive" against Cornonavirus disease a few weeks ago.

The AYUSH ministry issued a health advisory and recommended that homeopathic and unani medicines could be effective in the prevention of novel coronavirus $(\mathrm{nCoV})$ infections.

\section{Preventing ourselves from the spread of COVID 19}

To prevent infection and to slow transmission of COVID19, do the following:

- Wash your hands regularly with soap and water, or clean them with alcohol-based hand rub.

- Maintain at least 1 metre distance between you and people coughing or sneezing. 
- Avoid touching your face.

- Cover your mouth and nose when coughing or sneezing.

- Stay home if you feel unwell.

- Refrain from smoking and other activities that weaken the lungs.

- Practice physical distancing by avoiding unnecessary travel and staying away from large groups of people. (16)

\section{Conclusion}

Homeopathy is used since the time of the epidemic Hahnemann, who used Scarlet Fever for Belladonna. Several methods since then, it was suggested to use homeopathy for epidemic diseases. From the above review shows that the homeopathy medicine can treat all kind of disease in every parts of the body especially in epidemic, pandemics. But, the only fact is there is no much more research papers in the field of homeopathy. If the more papers are published to the government then the homeopathy system can be more authorized by the Government.

\section{References}

1. Nemati M, Ebrahimi B, Nemati F. Assessment of Iranian Nurses' Knowledge and Anxiety toward COVID-19 during the Current Outbreak in Iran [Internet]. Archives of Clinical Infectious Diseases. Kowsar; 2020, 15, [cited 2020 Apr 28]. Available from: http://archcid.com/en/articles/102848.html

2. Zhou M, Tang F, Wang Y, Nie H, Zhang L, You G et al. Knowledge, attitude and practice regarding COVID19 among health care workers in Henan, China. Journal of Hospital Infection [Internet]. 2020 Apr 9 [cited 2020 May 5]; 0(0). Available from: https://www.journalofhospitalinfection.com/article/S01 95-6701(20)30187-0/abstract

3. Modi PD, Nair G, Uppe A, Modi J, Tuppekar B, Gharpure AS et al. COVID-19 Awareness Among Healthcare Students and Professionals in Mumbai Metropolitan Region: A Questionnaire-Based Survey. Cureus Journal of Medical Science [Internet]. 2020 Apr 2 [cited 2020 May 5]; 12(4). Available from: https://www.cureus.com/articles/29822-covid-19awareness-among-healthcare-students-andprofessionals-in-mumbai-metropolitan-region-aquestionnaire-based-survey

4. 20-256651.pdf [Internet]. [cited 2020 May 5]. Available from: https://www.who.int/bulletin/online_first/20256651.pdf

5. Hamid S, Mir MY, Rohela GK. Novel coronavirus disease (COVID-19): a pandemic (epidemiology, pathogenesis and potential therapeutics). New Microbes New Infect. 2020; 35:100679.

6. Wertheim JO, Chu DKW, Peiris JSM, Kosakovsky Pond SL, Poon LLM. A Case for the Ancient Origin of Coronaviruses. J Virol. 2013; 87(12):7039-45.

7. Coronavirus [Internet]. [cited 2020 May 13]. Available from: https://www.who.int/westernpacific/healthtopics/coronavirus

8. Modes of transmission of virus causing COVID-19: implications for IPC precaution recommendations [Internet]. [cited 2020 May 13]. Available from: https://www.who.int/news-

room/commentaries/detail/modes-of-transmission-ofvirus-causing-covid-19-implications-for-ipc-precautionrecommendations

9. Publishing HH. Treatments for COVID-19 [Internet]. Harvard Health. [cited 2020 May 14]. Available from: https://www.health.harvard.edu/diseases-andconditions/treatments-for-covid-19

10. Principi N, Esposito S. Chloroquine or hydroxychloroquine for prophylaxis of COVID-19. The Lancet Infectious Diseases [Internet]. 2020 Apr 17 [cited 2020 May 14];0(0). Available from: https://www.thelancet.com/journals/laninf/article/PIIS1 473-3099(20)30296-6/abstract

11. Desk THN. Watch | Convalescent plasma therapy for COVID-19 patients. The Hindu [Internet]. 2020 Apr 18 [cited 2020 May 14]; Available from: https://www.thehindu.com/sci-tech/science/plasmatherapy-for-covid-19-patients/article31373992.ece

12. Jacobs J. Homeopathic Prevention and Management of Epidemic Diseases. Homeopathy. 2018; 107(03):15760.

13. Lives saved by Homeopathy in Epidemics and Pandemics | Āgenskalna privātklīnika [Internet]. [cited 2020 May 14]. Available from: http://www.similia.lv/interesanti/par-homeopatiju/livessaved-by-homeopathy/

14. William Boericke-Pocket Manual Of Materia Medica.pdf [Internet]. [cited 2020 May 15]. Available from:

https://www.homeopathybulgaria.org/todormed/WILLI AM\%20BOERICKE-

Pocket\%20manual\%20of\%20materia\%20medica.pdf

15. Arsenic: Uses, Side Effects, Interactions, Dosage, and Warning [Internet]. [cited 2020 May 14]. Available from: https://www.webmd.com/vitamins/ai/ingredientmono1226/arsenic

16. WHO EMRO | Questions and answers | COVID-19 | Health topics [Internet]. [cited 2020 Apr 28]. Available from: http://www.emro.who.int/health-topics/coronavirus/questions-and-answers.html 